\title{
9
}

\section{'Pain Is Hard to Put on Paper': Exploring the Silences of Migrant Scholars}

\author{
Despina Tzimoula and Diana Mulinari
}

\subsection{Introduction}

Despite the successful collection of thirteen life stories of working-class women of Greek background, in their late sixties, who had migrated to Sweden in the 1970s, the two researchers engaged in the research project-Despina, herself a child of migrant Greek parents, and Diana, a political refuge from Argentina-were unable to publish the results. The life stories they collected provided a rich and relevant empirical material on the significance of transnational migration, family bonds and labour. The recorded material was transcribed and more than fifty pages of preliminary analysis was written. The central topic emerging from the material was that of suffering: bodily as well as psychological; the pain of living

D. Tzimoula (凶)

Department of Childhood, Education and Society, Malmö University,

Malmö, Sweden

e-mail: despina.tzimoula@mau.se

D. Mulinari

Department of Gender Studies, University of Lund, Lund, Sweden e-mail: diana.mulinari@genus.lu.se 
outside the 'homeland'; and the sacrifices they made for their children. We never published the results.

We 'forgot' the project, engaging in other academic journeys as the years went by. In the period that followed, we 'remembered' the project every time we met and attributed our inability to conclude it to the demands of a neoliberal academy. We had carried out the research without any financial support and our survival as migrant women in the academy demanded other priorities. It can be argued that unstable working conditions-Despina, a doctoral student, Diana, a post doc with a oneyear contract at the time-may explain in part our inability to explore the voices we had heard in our extensive dialogues with these women. This rational interpretation was (and is), to a certain extent, true and decrease our emotional discomfort when 'remembering "the almost finished articles" we had never submitted for publication. But rational explanations regarding our working conditions do not tell the whole story. We have now, more than ten years after the collection of the empirical material, tried another interpretation We will argue that our inability to submit our work for publication can be also understood as our inability to conceptualise the immense experience of suffering that the empirical material provided. We were unable to analytically grasp the level of pain, the impressive suffering, the depressive emotional edge that the research subjects both expressed and acted upon. We were also unable to respond to our own feelings of shame and guilt created by the encounter with these experiences.

The aim of chapter is to listen to women's narratives by introducing into the conversation the concept of social suffering employing a psychosocial approach (Frosh 2010). The aim of the chapter is also to explore our inability (as migrants and daughters of migrants ourselves) to acknowledge what over-exploitation, gender and racial regimes can do and do to people, regarding their sense of self and well-being. The chapter moves through four sections. First, the text provides a short introduction to the Swedish racial formation followed by relevant efforts to conceptualise human pain, inspired by the work of the Black British feminist scholars Yasmin Gunaratnam and Gail Lewis (2001), which suggests the value of a synthesis of politicised psychoanalytic approaches to the dynamics of 'race' and emotional labour; bridging a reflection of our own 
emotions, with a special focus on shame and guilt. The central focus of the chapter is on the section 'What We Think Hurts the Most' exploring the stories collected and organised through three topics-(failed) motherhood, broken bodies and (racist) respectability.

\subsection{Swedish Racial Regime: Migrant Mothers, as Problems, Burden and Threat}

Sweden is frequently identified as one of the most successful projects of social-democratic welfare regimes with state-led gender-equality politics (Melby et al. 2008; Lundqvist 2011) and multiculturalism (Ålund and Schierup 1991). While Sweden continues to still score high in various evaluations of social justice, an increasing number of scholars point to the country's radical shift towards neoliberal policies at the beginning of the 1990s (Boréus 1997) with an impressive increase in class inequalities, the success of ethnonationalist political parties and a deep transformation of migration and refugee politics towards the securitisation and criminalisation of vulnerable groups (Ålund et al. 2017).

The contribution of a new generation of Swedish postcolonial fiction writers to the re-reading of gender, nationhood and migration is impressive (Pascalidou 2009; Wenger 2001; Farrokhzad 2013). We want to take a point of departure in migrant mothers' stories because their voices challenge one of the deepest forms through which gendered racism (Essed 1991) has been written on migrant women's bodies in Sweden: racist fantasies about their inability to productively engage in paid work, understood within Swedish workfare ideology as the only path towards women's emancipation. These childhood memories, these personal biographies of growing up as children of migrant mothers that paradoxically were not recognised as 'real' workers witness on the historical role migrant women had in the establishment of Swedish welfare (Knocke 1991; de los Reyes 1998, 2000; Strollo 2014), but also on the lack of collective societal memory in acknowledging their contribution.

Despite diverse sources pointing out the fundamental role that paid work played in migrant women's lives, Swedish labour market and 
gender-equality policies have for more than forty years analysed the problem of migrant women as their inability (or resistance) to participate in the formal labour force. The location of the category of migrant women within the Swedish racial formation in the last fifty years provides both systematic continuities and vital transformations. Continuity can be traced in the implementation of racist classification systems based on the binary opposition between the West and the Rest (Hall 1992). Similar to the discourses on migrant women in the UK analysed by Umut Erel (2011: 32), hegemonic discourses on migrant women in Sweden represent migrants' culture as patriarchal and oppressive, provide an understanding of migrant women located (or imprisoned) between modernity and tradition, a reading of migrant women's as recipients of benefits rather than contributors framed by an Eurocentric arrogance shaped by the conviction that Sweden, with its gender-equality ideology, opened through the provision of paid labour, a path towards the empowerment of migrant women. Intersectional analysis (Collins Hill and Bilge 2016) illuminates the diversity and multiplicity of migrant women's background with regard to class, sexuality, ethnicity, nation and religion beyond the construction of the category. Racialisation processes had different impacts upon women and men and also for different groups of migrant workers. Migrant workers from Finland suffered processes of racialisation during the 1960s and the 1970s but were constructed as 'Nordic' in the 1990 s (Borg 2016; Laskar 2017). Transformations can be identified among others in the subject positions opened for women target by the category: a problem in the 1970s, a burden in the 1990s and a threat today (Mulinari and Lunqvist 2017).

Central to our understanding of how differences have been acted upon in the different historical phases is, on the one hand, the continuity of a race formation based on Eurocentric frames at the core of a national narrative of modernity and progress but also the transformation of this racial regime over the course of the past fifty years. A way to understand the continuity in these different shifts is to differentiate analytically between three periods: the first one with social-democratic hegemony from the beginning of the 1960s, a context of subordinated inclusion where migrant values and cultures are to be acknowledged, and up to a certain extent learn from, and where migrant women are often invisible in social 
policy and when visible identified not as what they are: a segment of the Swedish working class, but as family members, their supposed 'isolation' a problem to be acted upon by state institutions aiming towards integration. The second period, following the 1991 financial crisis and the high level of unemployment and sick leave among migrant women introduces the notion of people being torn apart by what are supposed to be two cultures, with the codeword of cultural conflict and a conceptualisation of migrant women as a burden for the welfare state. In the last decade, we witness the establishment of a third category within an increasing racist racial regime where migrants' cultures are only defined by the patriarchal violence as a central quality of their cultures. However, migrant women are not only conceptualised as a threat, but also especially qualified for care and domestic work.

The experience of racialised gendered labour migration of our research subjects and particularly the levels of over-exploitation of their labour was located within the functioning of 'normal' capitalism, in the context of a welfare state with multicultural social policies. One possible interpretation evolving from our material is that for all those engaged (it is normal, things are like this, it is their country, it is natural we were guests here), racism was not only naturalised, but also seldom recognised.

\subsection{Social Suffering and Racist Practices}

In our study, racism is experienced in visceral, affective and embodied terms, and the consequences of these experiences is at the core of the stories of the working-class migrant women that we spoke to. The lack of societal public recognition of their suffering reinforces the levels of pain and bodily discomfort that we find in our research subjects.

In recent years, scholarship has both challenged understanding of the self as separated and abstracted from the social and deterministic understanding of subjectivity solely reduced to the reproduction of social hierarchies.

Scholarly traditions searching to transcend the binary opposition between rationality and feelings and drawing feelings to the core of the social has provided new ways of understanding trauma, loss, pain and 
vulnerability at the crossroads between self and society (Frost and Hoggett 2008; Ahmed 2004).

Sociologist Pierre Bourdieu's concept of social suffering as developed in his work The weight of the world: Social suffering in contemporary society (Bourdieu et al. 1999) draws attention to the lived experience of inhabiting social structures of oppression. The strength of the concept lies in its ability to grasp the subjective experience of loss and harm experienced by the (hidden) injuries different groups of people confront within neoliberal capitalism. An analysis of process of self-denial and bereavement had already been identified in industrial workers when excluded from the prospect to value themselves through their labour (Sennett and Cobb 1973). In Bourdieu's version, the concept provides an analytical frame where the pain produced by unequal relations of power is identified, recognised and acknowledged, or rather the term provides a conceptualisation of the levels of social misery, of feelings of humiliation, resentment, despair that result from what political, economic and institutional power do to people.

It is in the field of health care where the concept has had its most powerful impact. The concept has inspired anthropologists, critical psychologists and health care professionals identifying ill-health among unprivileged groups to create a space of understanding outside the scope of medicalisation and individualisation. The concept provides an antidote towards the reading of grief through psychiatric diagnosis of clinical depression, post-traumatic stress and mental illness (Wilkinson 2014). While the concept has been criticised for a number of reasons (McRobbie 2002), the term recognises the need to conceptualise suffering without falling into individualised and pathologised forms of victimisation.

Feminist scholar Yasmine Gunaratnam further develops the concept when working with migrants in palliative care. In her own words:

It is perhaps not surprising that such forms of suffering can manifest at the end of life for socially disadvantaged migrants, where lives are looked back on, regret and losses can (re)surface, and selves and bodies can become both more salient and more vulnerable as illness progresses and also at different stages of the care pathway that involve varying degrees and rhythms of exposure. (Gunaratnam 2012: 110) 
Increasing number of studies identified migrant women to be at a greater risk of developing mental health problems (Lindqvist 2013). While our research subjects were not suffering the distress of dying, most of them where retired and facing the dilemmas of both ageing and old age, dilemmas that reinforced their condition of migrants and particularly the ways through which they remembered their earlier experience of migration, family and labour. It seems possible that by adding a feminist and inspired explorations of affective practices (Wetherell 2015) to the notion of social suffering to conceptualise gendered racism(s) as a specific form of human suffering.

A central contribution of psychoanalysis to postcolonial work Stephen Frosh argues (2013) is to provide a vocabulary that facilitates discussion of what might be called the 'excessive' dimension of racist discourse.

A psychosocial frame provides a productive point of departure to explore fundamental 'visceral' and unconscious emotions of love, hate, aggression and envy at the core of racist affective practices. Michael Rustin suggests that 'Theories which don't take note of these psychic roots of racist practices can't adequately account either for the deep pain and damage they cause to their victims, or for their persistence as a social pathology' (1991: 68). And, according to Simon Clark (2003), a Kleinian psychoanalytic interpretation of racism is a fundamental point of departure 'to explore the ubiquitous and visceral elements of racial hatred and discrimination. ... It is the communicative aspect of Kleinian psychoanalytic theory which can help explain the ways in which we think of others, feel about others and, crucially, how we make others feel' (Clark 2003: 123). The reading of the social inspired by the work of Frantz Fanon's work $(1952 / 1968)$ is fundamental because it both challenges psychoanalysis at its core and further develops the tradition, moving originally between the sociopolitical and the psychological and developing a critical awareness of the role of societal setting (colonialism, racism) play within the domain of the psychological. Fanon's existential reading of psychoanalysis explores how central the construction of the other as an object is at the core of the construction of the coloniser as a subject and puts the issue of colonial power and racist desire at the centre of this relationship. In his path-breaking development of Marx's 'theory of alienation', Fanon poses an emphasis on the denial of the colonized humanity: 
Because it is a systematic negation of the other person and a furious determination to deny the other person all attributes of humanity, colonialism forces the people it dominates to ask themselves the question constantly: "In reality, who am I?." (Fanon 1968: 250)

An argument and insight further developed by feminist philosopher Judith Butler (1997: 139) identifying historical context when experiences of loss are foreclosed, because there is no public recognition through which the suffering can be named and mourned. The notion of the moral third, so central to the work of feminist psychoanalyst Jessica Benjamin (1988), explores how a Kleinian-inspired psychoanalytical tradition could conceptualise reparation. Acknowledgement of injury and misrecognition becomes an essential quality of repair, providing affective practice, that resists racist fantasies that only one can live, Benjamin (2004) argues.

\subsection{Methodological Reflections}

In recent decades, the turn to reflexivity, which emphasises the researcher's experience in the encounter with its research subjects, has expanded (Macbeth 2001; Berger 2015). Our location within a tradition of reflexive feminist methodologies (Jagger 2008) confronted us with a number of methodological puzzles. Trained in feminist research methods, issues of reflexivity and positionality have been at the core of our scholarly work. Despina is (in Sweden) categorised as second-generation GreekSwedish, a gendered Swedish citizen that has 'an unusual surname' and a skin complexion that will make her have to explain to the border officers, in her affluent Swedish that she 'belongs'. Diana is a political refugee from Latin America and she recognises very well the pain of forced migration and exile that of being separated (cut off, in the words of one of our research subjects) of family and kin.

The risk of a narcissistic shift from the voices of the research subjects to what is supposed is the internal life of the researchers has been identified by a number of authors. Daphne Patai reads the focus on self-reflexivity as the privilege of academics engaged 'in the erotic of their own language 
games' (1994: 69). While we agree with these and similar arguments, we also identify with a tradition of scholarly research that explores the possibilities of doing research in different ways and underlines the centrality of listening, or rather the art of listening (Back 2007), conceptualising the meeting between research and research subject as one of dialogue and working through notions of learning as equals. Wand Pillow (2003) introduces the notion of uncomfortable reflexivity, asserting that it is fundamental to challenge the use of reflexivity as a method to legitimate qualitative research and get access to better data; arguing for the need to move away from comfortable uses of reflexivity to what she defines as a reflexivity of discomfort, a concept and an invitation to a practice that we would argue is relevant for our research.

When we did the collection of the life stories in 2010, we decided to shift so that Despina, who has a Greek background and was a single woman during the period of the fieldwork, and Diana, who has a Latin American background and was already a mother of five, would encounter the women separately, so that we could be able to grasp the diversity of narratives that these two research positions created opening for the women to speak Greek with Despina, and sharing broken Sweden when Diana conducted the interviews. Our fieldwork notes witnessed positive feelings during the collection of stories, it seems that we both enjoyed the conversations and find pleasure in the company of our research subjects:

I stopped the machine after two hours ... We could continue forever. What a storyteller ... So much to tell

We stopped the recording when she began to cry. But she wanted us to continue and we did as she wanted. And she was right ... Beautiful how she remembers.

There were many potential benefits evolving from our insider positions not only for the 'access to the field' but also in our capacity for empathy and our acknowledgment of their pain (Chavez 2008). The feeling of being not only welcomed, but also in different ways the feeling of being at home or of coming home, a feeling of being at ease with the research subjects created the space for the successful collection of stories but also for what was to come, our own silence, our inability to publish. 
What follows is an attempt to develop analytical tools to be able to grasp our informants' experience without victimisation. We would like to argue that alongside an historical and sociological analysis of the narratives, a psychoanalytically informed reading, within the tradition of psychosocial studies creates a relevant approach to the conflictual nature of their experience (and ours).

\subsection{What (We Think) Hurts the Most: The Political Economy of Social Suffering-Always Wrong, Always Out of Place (Mothers)}

It is a curse to be a migrant (Maria).

Scholars on the Greek diaspora suggest that there has been a tendency to provide essentialist understanding of the Greek experience of migration based on the notion of a 'traditional family'. There is, however, no doubt that family and kinship relations are at the core of survival strategies regarding migration and that the experience of transnational households in terms of allocation of material and symbolic resources between Greece and migrant locations is at the core of the cultural understanding of obligations and rights in family matters (Markopoulou 1981; Tzimoula 2008).

In our empirical material, women's narratives change from description of events to visible emotions, stories told when crying, when migration stories entangle with the topic of doing family within transnational families: As an effect of the Second World War and a devastating civil war in the 1950s, Greece experienced yet another massive flow of emigration. It is to this flow our subjects in this study belong to, all of them arriving in Sweden in the 1960s and 1970s (Boukas 1993; Corvino and Kazana 1984).

Somebody we knew told us that we could work for him in a pizzeria. We left our two daughters with my husband's parents, the one was six and the other was one and a half. I really regret that. I am not leaving my children again. (Panagiota) 
Feminist scholars have identified the centrality of mother-work within migration studies that often untheorized gender (Brah 1996; HondagneuSotelo and Avila 2003; Phoenix and Bauer 2012). The experience of migration has, up to the present day, not been thought through the impact migration has on the rights of women to mother and in the right of children to be with their significant others. In our empirical material, women's narratives change from a description of events to visible emotions, stories told when crying, when migration stories entangle with the topic of doing family within transnational families:

My mother wanted to keep him (the child) — it was very common that women left their children with their mothers in those days. It is wrong to condemn these women for that-they all did it out of necessity. I could not leave my child so I took him with me. First, I got a job for two months, then my sister worked for a while but we could not manage, we both had to work but what were we going to do with the kids? With pain I cannot describe I wrote a letter to my mother and told her that I would bring the boy to her so that I could work. So, my husband took him and went to Greece and left the boy with my mother. What a mother feels when she is separated from her child... there are no words that can describe it ... it is horrible. I am old now but those memories still haunt me. My son is now a grownup man and has a family but the pictures of the past. I cannot forget them and they still hurt. There was probably another solution than this, there was probably some authority that could have helped us. But we didn't know. I was always very close to my mother. She had several medical problems so we use to help each other out. She looked after the boy while I got a cleaning job here. The boy got used to her and she to him, they had a strong band between them. Can you imagine what I did to her when I took the boy with me Sweden? It hurt her tremendously We communicated by letters. In one letter that I send to my mother, I drew the contours of my boys' little hand. I will never forget my mother's reply. 'May you live happy, my daughter. May your children grow up and may you someday have grandchildren. And may they send you letters with the drawings of your grandchildren's hands'. I have asked my children never to do such a thing. It may sound melodramatic, ridiculous to you, but it really was horrible. I did it to make her happy but I pushed her deeper in her sorrow. (Irene) 
In Irene's narrative, the shame she feels for the suffering of her mother seems to be as devastating as the pain she expresses when being forced to leave her child behind. The metaphor of the children's hands as representing an absence is a powerful illustration of the experience of loss at the core of the everyday interactions of transnational families. Migration not only dislocates Irene as a mother but also damages the relationship with her own mother. Most of the women we spoke to shared similar stories and most of them returned again and again to this topic. Irene cries in different parts of the story. She is telling us what a traumatic event it is and how it hurts, how it does not stop hurting, how it hurts through life and how it hurts through several generations. The phrase: It is wrong to condemn women for this grasps the normative gender ideology within the diaspora, that both encourages migration but demands good mothering. While the researcher was also nearly in tears, Irene's need to 'defend' her right to her pain showed that she was, to a certain extent, ashamed of appearing melodramatic - a quality that racist representations locate among migrant women.

In her study of serial migration, The British social psychologist Ann Phoenix (2019) shows how the experiences of separation and reunion (and for the children the repetition of experiences of separation from significant others to be reunited with a mother they had never met) creates serious emotional wounds that shape relations between mothers and daughters throughout their life. Not only is migration gendered, but it is based on specific and particular gender ideologies, particularly and specific of motherhood: Who is a bad mother? Or, as feminists would put it, who is not a bad mother? To whom in the audience is Irene speaking when she defends hers and others' decisions of leaving the children behind. Why does she need to legitimise what would be for most observes an act based on care and love? Is this an explanation aimed to her son and towards the Greek-Swedish youth born and raised in Sweden? Why does she need to apologise for crying when any observer would understand her experience of suffering?

In the more than two-hour interview, Irene's pain (of leaving her son, of hurting her mother) was seldom linked to feelings of anger, the social (migration, over-exploitation, racism, male dominance) was constructed and accepted as natural: This is how things where, the Swedish are like 
this, it is their country, we were ignorant, we did not know better. Migrant women's traumatic experiencing of separation and loss was reinforced by the Eurocentric discourses they encountered in Sweden, which demanded not only their entrance into paid work, but also their 'integration into the mythical space of Swedish modernity, an "integration" that was fundamental, it was argued, to break their 'isolation' and allow them to be good mothers. The notion of being ignorant (the term most used) appears also in how women in most stories explained, how they worked shifts, seldom using child-care facilities, but there is not only shame, there is also pride in being 'good migrant workers', of not 'exploiting the system' in 'made it in our own'.

The construction of the migrant women/mothers as culturally different can be found in a government commission report in 1979, investing the future immigration policies (SOU 1974/1979). Note how Irene is constructed (despite her experience of migration and active labour market participation) as a passive object, acting upon external demands, from both her children and husband. Note also how the binary opposition between tradition and modernity locates her outside the realm of the Swedish gender equality discourse; not only does it obscure her skills as a worker, but also stigmatises her as a mother:

The collision between on the one hand the immigrant woman's upbringing and background, and the norms and values of Swedish society on the other, make it very difficult for her to function as a mother and wife. While she is tied to her own tradition and role as a woman, she is also asked to meet the changes to respond to the demands of her children through school and friends. Moreover, her husband demands her to maintain her traditional female role. (SOU 1974. Quoted in Knocked 1991: author's translation)

In the following quote, Eleni challenges Swedish welfare/social work discourses on the needs of children and good mothering, by telling a story of going out for dinner with her son:

Sure, I could go out for dinner from time to time. Once I went out with a Swedish friend and her daughter who is 4 years older than Dennis. Dennis was six years old. It was around 20.30 or 21.00 in the evening and every- 
body was looking at us very strangely. I couldn't understand why. 'is there something on my clothes+'. I ordered a steak for me and one for Dennis, what can I say ... he ate a lot! (laughs). That's why they look at us, they thought I was crazy to spend money on my kid's food, not ordering something small and for kids. They probably also though that we were bad mothers going out with our kids at that hour. In Greece we are out at 23.00 or 24.00 It's my right to go out at any hour I like, it doesn't make me a bad mother. (Eleni)

Eleni was very conscious of the power of the gaze looking at her and her child. She seemed proud when telling the story but also mediates the discomfort of feeling controlled and judged. The story grasps the tensions of the goodwill of multicultural policies during the late 1970s, based on respect and tolerance of migrant cultures, when these cultures were not acted upon in public spaces and particular when the so-called 'migrant cultures' had an impact on the 'migrant child' already created as an object of institutional intervention and preoccupation.

If there is pain in leaving the children, and pain in being categorised as a bad mother in Sweden, there is also shame when unable to fulfill the ethnonationalist demands of the Greek nation-state, which underlines that the reproduction of the nation in the Diaspora is a vital role for women (Umut 2011), a reproduction of the cultural boundaries of Greekness that demanded strategies of motherhood aiming at raising children identified with the fatherland, despite children's experiences of belonging to other places and spaces.

Being a Greek mother in a Swedish context demands extreme efforts and sacrifices and all of them make the statement that they did all they could. In the words of Eleni:

It has been extremely difficult! I have tried to be as Greek as I could in my methods, and we made sure to go to the Greek Orthodox Church on the major holidays. you know. I try to keep all the traditions I can. But the Swedish are strong. 
A more tired and capitulating attitude towards raising children in what she (despite living in Sweden for more than forty years names as a foreign culture) is articulated by Soultana:

It is really hard to transmit a culture surrounded by another one. But the truth is that the Swedish culture has taken over. That have made me sad many times but that how it is. (Soultana)

This practice, the doing of Greekness, recreating culture and tradition in the Diaspora towards the creation of a new generation of Greeks, trying to maintain the 'Greekness' in the children proved to be a difficult and almost impossible task. If that task is unsuccessful the blame can only fall on the mothers. Olga illustrates her frustration with the following words:

...When these kids can't connect with Greek tradition, language, culture, the only ones to blame are the mothers. I have seen themselves into a Swedish way of life, thus dragging their children with them, and when the time for them to move back to Greece, the children do not wish to follow and that hurts the parents. But it is too late. These children cannot master any language right, not the Swedish and not the Greek. (...) but who is to blame? The mothers of course!! Then there are families that do not have that problem and their children really want to go to Greece. Why? I will tell you why - they go to Greek school they get feedback from home, they go to Greece frequently and their parents really try to transmit the Greek culture to them. (...) pride for the homeland. And if this is allowed to continue there is not going to be a Greek community in Sweden. It's going to be lost. If the second generation is on the edge of going lost, what will happen to the third? they will probably not even be called themselves Greeks (Olga)

All of the women we spoke with tell us that they did all they could but that most of the time what they did was not enough. There is little joy in the stories, the space of motherhood is inhabited by shame; both when leaving the children in Greece, when experiencing the majoritarian gaze in public spaces identifying them as bad mothers and when 'failing' to educate the children following the cultural mandate of the Fatherland. Their narratives highlight the experience of gendered migration in terms 
of the experience of being violently cut off from family bonds. A form of social suffering where ethnonationalist patriarchal demands, labour migration and racism create an affective space regulated by shame, or rather by gendered coded shame.

\subsection{Good Workers: Sacrifices, Bodies and Racism}

You want to know how we got here?! Then you are going to write a big book, sweetheart. The pains and tortures of the Greek are hard to put on paper. (Fotini)

I have noticed that I have been treated differently because I am foreign. At work for instance I would always get the hardest jobs, the heaviest. We always got the hardest and dirties jobs there was. Maybe it was because we didn't know the language. We were ignorant. And we never complained, we took whatever job they offered us. We needed the money and the Swedes knew that and took advantage of it. (Eleni)

During the 1960s Swedish labour migration was regulated by migration policies that recognised migrants' rights and provided autonomous legal status to migrant women. While migrant women had access to formal citizenship rights, they were located in subordinated positions in all spheres of life (Ålund and Schierup 1991). A racialised division of labour located different groups of women in different sectors of the labour market. While Swedish women also entered the labour market to take up paid work in the public sector at this time, migrant women tended to be located in the private sector, with higher employment rates (de los Reyes 2000). This specific period of time may be conceptualised in terms of subordinated inclusion, grasping the establishment and development of what was emerging as a Swedish racialised working class (Mulinari and Neergaard 2014).

If the pain and the suffering created by the experience of transnational motherhood is one of the most relevant topics in the life stories, their 
own bodies, or rather the pain produced by hard work in their own bodies is also a highly present topic:

I was young when I came here, 23 years old. You think differently when you are young. I thought that I could just leave whenever I wanted to, but ... of all the dreams I had then, nothing came true. I stayed here. I worked, destroyed my body and I was an old lady before my 50th birthday. (Olga)

The destruction of their bodies appears to be of a different character than the pain expressed by the (negative) experiences associated with mothering. In their narratives, despite the physical pain, there is pride in their bodies' scars, they see the destruction of their bodies as a proof of what they themselves define as 'good workers', as one of them put it: working hard, not minding the fragility of our bodies. Being a good migrant was to be a good worker. To be a good worker called for certain sacrifices, particularly of the (working) body:

Those were difficult times. I remember one night when I was working at a hotel, washing dishes. I didn't have any specific timetable, I was supposed to work as long there was dishes to wash. That night it wasn't that much to do and one man wanted to tell me that I could home earlier. He was talking to me but I didn't understand and continued to wash the dishes. Finally, one older woman working there came, took me by the shoulders, untied my apron and put both her hands to her ear and bowed her head as if she was sleeping. Then I understood, she was trying to tell me to go home and sleep. When I came home, I remember I cried. I felt ashamed and sad. They were speaking to me and I didn't understand a word. I felt ... I don't know... lost. (Maria)

It is not the hard work that is the point of this story, even if the hard work is a central organising topic in how Maria remembers her experience. What is crucial here is the feeling of shame, of not being able to understand. No labour union regulation, no working contract frames the event; with Maria 'remembering' the inability to translate the existing cultural codes, her inability to understand the language: 
(...) and then we moved to Åseda. I don't really remember. and we stayed there for a year or something. It was there I had an accident. I worked with men, you know they were melting iron, what is that called? They did metallic stuff for construction, you know. I worked with the owners' twins' sons. They were fifteen years old, I was seventeen. And it was there I had my accident. My hand got caught in the machine and the skin of the hand and the arm, up to my neck was ripped off. They were really nice to me, they took me to the hospital ... I was so ashamed, you know I didn't speak the language or anything. (Eleni)

Shame was the feeling most present when speaking about mothering, shame (of not understanding what is being said, of not speaking the language) is present in the narratives about work. While she was seventeen and the accident shaped all her life, Eleni's memories focuses on her embarrassment in not being able to communicate with the health care professionals. She uses the term 'nice' to describe how she was treated. Maria also tells us about her own accident as an effect of her working conditions:

I started working in a factory where they made typing machines. There I had the first big tragedy of my life. My hand got caught in a machine and ripped of pieces of two fingers (showing the injured hand). Then reality hit me. I had left a rather good life to go to a country I did not know anything about and become an invalid. I felt useless, invalid, all sorts of things. One could say that that was the first marking Sweden did upon me. (Maria)

I was young when I came here, 23. You see things differently when you are young, I thought that I could just leave whenever I wanted to, but. All the dreams that I have then, nothing came true. I stayed here, I worked, destroyed my body and I was an old lady before my 50th birthday. Why didn't I leave? I don't know. Started working, I didn't have social security in Greece, then I thought, "next year" and "a little bit longer", then I started school. While in school I had a car accident, so I stopped for a long time. Then I started working again, then I stared school again and had another accident at work which damaged me a lot. Then I reached an age which made it difficult for me to find work in Greece. I don't know. Why I'm still here... coincidence maybe. We think that we are going to be young forever, 
you know, the usual stuff. Then I have to say that my ego held me here, that I worked here and contributed to something here, but nothing in Greece, I couldn't just leave. I felt that Sweden had its obligations against me since I had worked here for so long, I gave them hands, my youth. To Greece I gave nothing, so I can't demand anything from Greece as I can from Sweden. And then of course there was the accident at work that kept me here. (Olga)

Olga is of a different character; the accident forces her to read her migration as one from leaving a position of relative privilege in Greece to one of being disabled. However, Olga is not angry either. The anger turns her in on herself, making her feels that she is the one without value. She reads the accident nearly as a proof of her loyalty to Sweden, of what she has given this country: concretely, her hands.

\subsection{Social Suffering and (Racist) Respectability}

Then I came to Malmö, I had bought a hairdresser salon, not the one you came to, another one. and so, life goes on. But you cannot imagine. just in that little salon I have, do you know how much racism there is among the old ladies?? It's unbelievable! And unfortunate! So many years, 33 years in Sweden and-because I understand the language better now. it hurts more, it gets to us more now. I think it is so because. no. and they show it too, very much 'don't go to her-she is an immigrant. Got to our girls' ... 'what are you saying?' They are funny (laughs). They don't know me, how can the judge me? I mean, I haven't worked in Greece at all, I came here when I was very young. I had never been a burden, never cost the state anything. free labor power you know. We went directly to work and paid our taxes... (Eleni)

Eleni speaks about racism in terms of an increase in pain when she could understood the culture and the language. Lack of 'integration' in the earlier years protected migrant women from the most vulgar everyday forms of racism, according to Eleni: not understanding made the possibility of ignoring racist practices easier. Today, Eleni understands and understanding produces more pain. 
The success of the ethnonationalist political party the Sweden Democrats (today the third party in Sweden with more than 20\% of electoral support) illuminates societal shifts from the social democratic hegemony that received the Greek labour migration in the 1960s and 1970 s to a neoliberal regime with authoritarian ethnonationalist edges. Both in public discourse and among mainstream political parties the category of migrants is often spoken through notions of burden (how much they cost) or/and notions of threat (migrants threating gender equality, Swedish values, etc.). Irene describes this experience in the following way:

They see us as different. They see our dark hair, the color of our skin and ... lately things have been happening to migrants that are scaring us. If I go to somebody's house, my sister's our/my cousin's, my husband always warns me of coming home after dark. We are scared. This racist thing is getting worse ... you have to watch yourself. It's wrong. It's a huge injustice. I don't speak of all Swedes, there are good people too. I can't describe how it feels, we have helped Sweden develop, we have been a part of the machinery and now they, the Swedes turn against us. It makes me feel even more inferior. To live in a place for thirty years and not feel at home, to feel a stranger. It's a big part of a lifetime. Many times, I feel that; that part has been wasted. (Irene)

Being afraid of neo-Nazi violence is today a sensible response to what is a real threat. Irene is right. Things can happen in the streets, migrants have been attacked and even killed by neo-Nazis (Gardell 2015). But what makes her statement relevant is how she links this feeling of being threatened by a feeling of lack of meaning, as if beyond the threat lied a deep pain of not being allowed to belong, their work not recognised, their contribution to society denied. Thirty years of her life defined as missed. In her narrative racism is experienced as an unfair classification system that includes her in a category, she does not recognise herself in belonging. In her narrative racism is a classification system so monolithic that her phenotypical characteristics (her dark hair) puts her and her family in the category of Others, despite her contributions to Swedish society. 
We can't fight with the Swedes. They are too powerful. So, we fight with the refugees (laughs). (Fotini)

Fotini's intervention mirrors the power of humour to name specific forms of pain. The conviction that the conditions imposed by the Swedish nation-state was (and is) impossible to resist or to challenge is followed by the reflection that these years of suppressed anger are now articulated against what is experienced as a much vulnerable group: the new wave of refugees.

He should be happy that I, among others came and saw that he and his country got a bright future. (...) I mean we worked and increased this country's welfare. Sweden was nothing before. Zero. We came and worked practically for free and made it what it is. They did nothing for us, I mean we didn't even go to school and now, now they kick us. Of course, that is why it gets to us, because we know that we contributed for so long and now they treat us like this. it's unbelievable. We cleaned up all their shit so that they could have a nice country to live in ... And then the new migrants are coming and getting everything for free in allowances. I know one family that gets 34000 a month from the state!! And I am working and paying taxes that are sky high! Can you imagine that!? They get paid for every child and they are six of them, they are divorced and they get something for that and so on, the money for the rent, the electricity, the phone, everything. 34000!! It's unbelievable! Yes, it is it's true. If I would need any help, I would probably get a big kick in the ass (laughs). (Eleni)

We carried out these interviews in 1999, one year after the creation of the ethnonationalist party the Sweden Democrats. Debates about nationhood and belonging where framed within a neoliberal discourse of costs and benefits, the category of migrant inscribed both in terms of burden for the welfare state and particularly for the Muslim population as a threat to Swedish values and norms (Integrationsverket 2005) in a context of increasing neo-Nazi violence and the presence of white supremacist terrorism (Gardell 2015).

In the last decade support for the ethnonationalist party the Sweden Democrats among foreign-born Swedish residents, both women and men while far lower than among Sweden-born men has increased 
(Mulinari and Neergaard 2018). While not all of them, some of our research subjects organise their stories through a timeline defined by the presence of new groups of migrants. The binary opposition between us and them and the qualities through which this binary opposition is created-good migrants/bad migrants — was often used to express feelings of anger and bitterness, towards as Swedish society that seem not to recognise their value, or rather was unable to differentiate them (as good migrant workers) from the newly arrived refugees.

Relevant to our analysis is how Olga reiterates what other research subjects have said, these longing for recognition, their conviction of being both exploited but proud in creating a wealth, that is not defined as theirs. The us and them in the narrative is constructed through what she experienced she received (nothing) and what she thinks this new wave of migrants receive (everything):

Some simple examples. For instance, the sick-leave, some years ago if somebody of 50 years had problems with his arm, he got retired and full pension. And now, look at me. I have it all, arms, legs, back problems and I have evidence, X-rays, statements from doctors, but still they don't believe me. I have worked, so I have pension points. You have to become pathetic to be believed, cry and so on. Otherwise they don't believe you; and there are others like me. I can't do that. And I have no problem saying it to them. and of course, then, they want names, they want me to betray the ones that are acting sick, that do not want to work, and tell them a lot of lies. I will not betray other people, I want them to believe me. I told one of the social welfare ladies that I know there are people that they believe are sick, receive the benefits and work on the side. That's wrong. I won't do that, I can live on my pensions' points I have, it's enough. but there are a lot of wrongs in this country. Many migrants use the system. We do not do that. (Olga)

One of the Sweden Democrats' propaganda video for the 2018 elections represented an elderly lady walking very slowly and trying to get to a table that represented the welfare state, being run up by women in (black) hijabs with their children. Instead of neoliberal policies legitimated by social democratic governments, a difficult reality to accept for a section of the Swedish population, the migrants are the one to blame for the crisis of the welfare state. Among the ways through which this blaming is acted 
upon is about false information (sometimes reproduced in the media) over the 'privileges' the refugees receive:

But when they needed us, we were welcome. we worked as animals. made this country work. and yesterday, I'll tell you about yesterday. I have had a bad back and I'm retired since xxx... so they send me to the orthopedic to determine exactly how this happened, if it was the heavy work or something else etc. so yesterday, I went to the hospital and I understood one thing: doctors are the greatest racists! Not towards the new refugees, but towards us. They came here with money, lied to the authorities and now everybody, me, your mother, father, my husband, everyone is paying for them... I am not a racist but this has made me one... since yesterday that is. The doctor asked me questions using medical terms I have never heard, where would I hear them - in the factory?! How can he demand from a worker to be familiar with medical terms?! I never went to school here because they only wanted us to work and produce, to go to school didn't produce anything... For them it was only the daily things we needed at work that had to be sufficient, other than that they didn't care. When I said I didn't understand the medical word he used for something, he turned to me and said: Don't you know the alphabet? Almost pissed off. I said that I did but not that words. So, he did something and said he was done with the examination and told me to get lost! No x-rays, no nothing. What do you think, isn't this racism?! We made Sweden what it is today, today they are rich. they take care of all those who haven't contributed to anything to this country and us. We worked and damaged our bodies and they don't care. What do you think? (Olga)

The narratives are similar. All of them begin with an understanding of the role their labour has had in the creation of Sweden as a prosperous country and conclude with the anger created by the fantasy that the new refugees are protected and love. Note that the ones allowing the level of over-exploitation that destroy their bodies is not also the target of the anger. Or rather the anger seems to evolve by what for them is the breakdown of a moral economy in which they thought that working hard and never complaining would create a space of respectability and inclusiona space that could protect them and their children from being the Others. 
At a descriptive level, the term respectability refers to seeking to make oneself socially acceptable through good or 'proper' behaviour. The concept of racist migrant respectability (Mulinari and Neergaard 2018) grasps the subject position that an increased number of labour migrants from the 1960s and 1970s take as a response to, on the one hand, the lack of acknowledgment of their contribution to society and, on the other, the danger that new migrant groups create from within, threatening their already marginal position.

\subsection{Concluding Reflections}

The analysis of emotions in fieldwork has expanded with the shift towards affect in social science and the humanities. However, the level of analysis focuses mostly on emotions that are clearly and consists acknowledged and often documented by the researcher. The psychoanalytical conceptualisation of the unconscious evolves within and through the clinical practice of psychoanalysis and the process of travelling and translation to the social is not only slippery but highly problematic, when psychopathologic terminology travels from the clinic to the social science and the humanities (Gordon 2001).

Our argument here is that we were unable to recognise these emotions. Or rather, these emotions acted upon our unconscious fears and paranoias in ways that decreased our capacity of concluding the research project. We are 'migrants' ourselves and we could not manage the pain that emerged from these narratives. While conscious of the role of racism, and even theoretically working in the area, there was something in the experiences evolving from the narratives we could not deal with. In other words: it is productive to differentiate between emotions, that are identifiable and acknowledged and unconscious processes of denial, paranoia, desire and projection that are nearly impossible to articulate, and that silenced not only the pain of our research subjects but also our own.

For both of us is was a painful experience to listen to these stories in the context of the powerful silence that existed both in society and social science regarding the contribution of migrant women to Swedish welfare. 
While we wanted to challenge representation of migrant women as passive and oppressed, our empirical material pointed to a category of people paralysed by their own suffering. While our interpretation was on the racism they have experienced and not in the Eurocentric discourses of their patriarchal cultures, we were unable to find ways to write their suffering without falling in narratives that reinforced Eurocentric representation of oppressed migrant women. Moreover, we did not find any productive strategies to the question of what researchers ('like us') should do when informants, people that we had learn to respect and love, express (racist) ideas that are stigmatising to other groups of people. Should assessments that we know most majoritarian readers will read through an Eurocentric gaze be excluded to protect the group, a group haunted by labour exploitation and racism?

We would like to suggest that our response to the pain expressed in the stories was (in our location as young migrant women) to dis-identify as much as possible from this earlier generation of migrants that was so paralysed by their nostalgia and loss. Increasing research identifies the tensions between so-called first- and second-generation migrants regarding responses to racism. The notion that the elder generation did not open challenge racism is a relevant topic among a generation born and raised in Sweden with a migrant background. This is our future, we told ourselves and laughed when reading the transcriptions.

In their reading of notions of guilt and shame, black feminist scholars Yasmin Gunaratnam and Gail Lewis (2001) suggest that while guilt is, within a Kleinian understanding, an opening for possible resolution, being guilt about an event may open an emotional conduct towards recognition. We did not felt guilt. We were ashamed.

We would like to argue that this paralysing emotional regime that made us 'forget' the research project was one of shame. We were ashamed of our research subjects. We were ashamed of our research subjects who could be our mothers and aunties. It was the same shame we felt every time family and kin made the majoritarian population uncomfortable by speaking too loud in the streets; laughing in the wrong places, or being so subordinated in their strategies to please; that the majoritarian population, the 'Swedes', felt awkward. We were ashamed that they (we surely felt even if we may be wrong) did not struggle against racism. A shame 
that was also framed through the experiences of dis-identification evolving from our newly achieved (class) location within the academy. A shame that was our unintended company in our interaction with the transcripts.

The internalisation of racism (the internalisation of misrecognition) identifies the coercive process, of projective identification through which projection of the bad into others acts upon the power to force the other to 'take in' what the self disposes of. In our own internalisation of racism, we could see our research subjects as those embodying the position of whiteness would see them. Perhaps not publishing was a defensive response, a strategy of protecting them and ourselves, an (infantile) resistance of both loving them and being angry and disappointed. Mostly we were ashamed of being ashamed.

Well, it's time to publish...

\section{References}

Ahmed, Sara. 2004. The cultural politics of emotion. New York: Routledge. Ålund, Alexandra, and Carl Ulrik Schierup. 1991. Paradoxes of multiculturalism. Essays on Swedish Society. Aldershot: Avebury.

Ålund, Aleksandra, Carl-Ulrik Schierup, and Anders Neergaard, eds. 2017.

Reimagineering the nation: Essays on twenty first century Sweden. New York: Peter Lang.

Back, Les. 2007. The art of listening. Oxford: Berg. Benjamin, Jessica. 1988. The bonds of love. New York: Pantheon. 2004. Beyond doer and done-to: An intersubjective view of thirdness. Psychoanalytic Quarterly LXXIII: 5-46.

Berger, Roni. 2015. Now I see it, now I don't: Researcher's position and reflexivity in qualitative research. Qualitative Research 15 (2): 219-234.

Boréus, Kristina. 1997. The shift to the right: Neo-liberalism in argumentation and language in the Swedish public debate since 1969. European Journal of Political Research 3: 257-286.

Borg, Kristian., ed. 2016. Finnjävlar. Stockholm: Verbal.

Boukas, Andreas. 1993. Greker i Sverige: En bit svensk historia, frain argonauterna till nutid/Greeks in Sweden: A piece of Swedish history, from the Argonauts to the present. Stockholm: Grekiskt bibliotek och arkiv i Sverige.

Bourdieu, Pierre, et al. 1999. The weight of the world: Social suffering in contemporary society. Cambridge: Polity Press. 
Brah, Avtar. 1996. Cartographies of diaspora: Contesting identities. London: Routledge.

Butler, Judith. 1997. The psychic life of power: Theories in subjection. Stanford: Stanford University Press.

Chavez, Christina. 2008. Conceptualizing from the inside: Advantages, complications, and demands on insider positionality. The Qualitative Report. 13 (3): 474-494.

Clark, Simon. 2003. Social theory, psychoanalysis and racism. 3rd ed. London: Palgrave.

Collins Hill, Patricia and Sirma, Bilge. 2016. Intersectionality. Maiden: Polity Press.

Corvino, Teresa, and Vasola Kazana. 1984. Grekiska kvinnor: Deras situation i Stockholm/Greek women: Their situation in Stockholm. Norrköping: Statens Invandarverk.

de los Reyes, Paulina. 1998. I skärningspunkten mellan genus och etnicitet. Ett ekonomiskt historiskt perspektiv på invandrarkvinnor i svenskt arbetsliv. Arbetsmarknad \& Arbetsliv 1: 13-31.

. 2000. Folkhemmets Paradoxer Genus och etnicitet i den svenska modellen. Kvinnovetenskaplig Tidskrift 2: 27-46.

Essed, Philomena. 1991. Understanding everyday racism: An interdisciplinary theory. Thousand Oaks: Sage.

Fanon, Franz. 1952/1968. Black skin, white masks. London: Zed Books.

Farrokhzad, Athena. 2013. Vitsvit. Stockholm: Albert Bonniers.

Frosh, Stephen. 2010. Psychoanalysis outside the clinic: Interventions in psychosocial studies. London: Palgrave.

- 2013. Psychoanalysis, colonialism, racism. Journal of Theoretical and Philosophical Psychology 33 (3): 141-154.

Frost, Liz, and Paul Hoggett. 2008. Human. Agency and Social Suffering In: Critical Social Policy 28 (4): 438-460.

Gardell, Mattias. 2015. Race warrior. Raskrigare. Seriemördare Peter Mangs. Stockholm: Leopold förlag.

Gordon, Paul. 2001. Psychoanalysis and racism: The politics of defeat. Race and Class 42 (4): 31-49.

Gunaratnam, Yasmin and Gail Lewis. 2001. Racialising emotional labour and emotionalising racialised labour: Anger, fear and shame in social welfare. Journal of Social Work Practice 15 (2): 131-148.

Gunaratnam, Yasmine. 2012. Learning to be affected: Social suffering and total pain at life's borders. The Sociological Review 60 (S1): 108-123.

Hall, Stuart. 1992. The west and the rest: Discourse and power formations of modernity, ed. Stuart Hall and Bram Gieben. London: Polity Press. 
Hondagneu-Sotelo, Pierrette, and Ernestine Avila. 2003. 'I'm here, but I'm there': The meanings of Latina transnational motherhood. In Gender and US immigration: Contemporary trends, ed. P. Hondagneu-Sotelo, 548-571. Berkeley: University of California Press.

Integrationsverket. 2005. Integration Board 2005. Rapports and case studies of racism and ethnic discrimination in Sweden. Integrationsverkers rapportserie 2005: 02. Stockholm.

Jagger, Alison., ed. 2008. Just methods: An interdisciplinary feminist reader. Boulder: Paradigm.

Knocke, Wuokko. 1991. Invandrade kvinnor - vad är "problemet?", Migrant Women. What is the problem? Kvinnovetenskaplig tidskrift 3: 4-15.

Laskar, Pia. 2017. Den finska rasen och görandet av svenskar, ed. T. Hübinette, 71-95. Ras och vithet. Svenska rasrelationer i går och i dag, Studentlitteratur: Lund.

Lindqvist, Mona. 2013. Speaking about social suffering?: Subjective understandings and lived experiences of migrant women and therapists. PhD. diss., Karlstads University.

Lundqvist, Åsa. 2011. Family policy paradoxes. gender equality and labour market regulation in Sweden 1930-2010. Bristol: Policy Press.

Macbeth, Douglas. 2001. On-Reflexivity in qualitative research: Two readings and a third. Qualitative Inquiry 7 (1): 35-68.

Markopoulou, Christina. 1981. Sociocultural effects of intra-European migration: A cyclical research study in Greece and Sweden. Sweden: Dept. of Sociology, University of Gothenburg.

McRobbie, Angela. 2002. A mixed bag of misfortunes? Bourdieu's weight of the world. Theory. Culture and Society 19 (3): 129-138.

Melby, Kari, Anna-Birte Ravn, and Christina CarlssonWetterberg, eds. 2008. Gender equality and welfare politics in Scandinavia: The limits of political ambition? Bristol: Policy Press.

Mulinari, Diana, and Åsa Lunqvist. 2017. Invisible, burdensome and threatening. The location of migrant women in the Swedish welfare state. In Reimagining the nation: Essays on twenty first century Sweden, ed. Ålund et al. London: Peter lang.

Mulinari, Diana, and Anders Neergaard. 2014. We are Sweden democrats because we care for others. Exploring racism in the Swedish extreme right. European Journal of Women's Studies 21: 43-56.

- 2018. A contradiction in terms? Migrant activists in the Sweden democrats party. Identities 2 (2): 12-25.

Pascalidou, Alexandra. 2009. Beyond my mother's street [Bortom mammas gata]. Stockholm: Pocket. 
Patai, Daphne. 1994. (Response) When method becomes power. In Power and method, ed. A. Gitlen, 61-73. New York: Routledge.

Phoenix, Ann. 2019. Situating Children's family troubles: Poverty and serial migration. Journal of Family Issues. 40 (16): 2310-2329.

Phoenix, Ann, and Elaine Bauer. 2012. Challenging gender practices: Intersectional narratives of sibling relations and parent-child engagements in transnational serial migration. European Journal of Women's Studies 19 (4): 490-504.

Pillow, Wanda. 2003. Confession, catharsis or cure? Rethinking the uses of reflexivity as methodological power in qualitative research. International Journal of Qualitative Studies in Education 16: 175-196.

Rustin, Martin. 1991. The good society and the inner world. London: Verso.

Sennett, Richard, and J. Cobb. 1973. The hidden injuries of class. New York: Vintage Books.

SOU. Swedish Governamental Inquiry. 1974: 69. Migrants and Minorities. Invandrarna och Minoriteterna. Stockholm: Fritzes. . 1979: 64. New migrant Law. Ny utlänningslag. Stockholm: Fritzes.

Strollo, Emma. 2014. In the land of gender equality. Historical and intersectional perspectives on labour migration regulation” I jämställdhetens land. Historiska och intersektionella perspektiv på arbetskraftsinvandringens reglering" i de los Reyes, Paulina (ed.), Inte bara jämställdhet. Intersektionella perspektiv på hinder och möjligheter i arbetslivet, Delegationen för jämställdhet i Arbetslivet, SOU 2014: 34.

Tzimoula, Despina. 2008. Eidola. Gender and nation in the writings of Penelope Delta (1874-1941). Lundiana: Lund University Press.

Umut, Erel. 2011. Reframing migrant mothers as citizens. Citizenship Studies 15 (6-7): 695-709.

Wenger, Alejandro Leiva. 2001. To our honour. Till vår ära. Stockholm: Albert Bonniers.

Wetherell, Margaret. 2015. Trends in the turn to affect: A social psychological critique. Body \& Society 21 (2): 139-166.

Wilkinson, Iain. 2014. The problem of 'social suffering': The challenge to social science. Health Sociology Review 13 (2)): 113-121.

Despina Tzimoula is Senior Lecturer at the Department of Children Education and Society at Malmö University. Tzimoula's main research interests are around the issues of gender, nation and education, with special focus on intersectionality. She has written on the issues of gender and nationalism: Eidola: Gender and Nation in the Writings of Penelope Delta (1874-1941) (2008); 'Identity and 
subjectivity in the works of Penelope Delta' (2010). Her newly published work explores the relationship between gender, the construction of the category of children and the national curriculum. 'After the century of the Child: Swedish Education and the Transformation of the Role of the Child' (with Peter Lilja) in Contextualizing Childhoods: Growing up in Europe and North America (Palgrave Macmillan 2018).

Diana Mulinari is Professor in Gender Studies at the Department of Gender Studies, Lund University, Sweden. The role of mothers in doing the political was the topic of her PhD in the Department of Sociology at the same university. Questions of colonial legacies, Global North/South relations (with a special focus on Latin America) and racism, and the diversified forms of resistance and organisation to old and new forms of power have stayed with her through all the work she has conducted. Her research has developed in a critical dialogue with feminist and other theoretical and methodological contributions that make a strong case for emancipatory social science. Relevant publications include Dreaming global change, doing local feminisms (Martinsson and Mulinari 2018); 'A contradiction in terms? Migrant activists in the Swedish Democratic Party', Identities (Martinsson and Mulinari 2018); and 'Exploring femonationalism and care-racism in Sweden', Women's Studies International Forum (Sager and Mulinari 2018)

Open Access This chapter is licensed under the terms of the Creative Commons Attribution 4.0 International License (http://creativecommons.org/licenses/ by/4.0/), which permits use, sharing, adaptation, distribution and reproduction in any medium or format, as long as you give appropriate credit to the original author(s) and the source, provide a link to the Creative Commons licence and indicate if changes were made.

The images or other third party material in this chapter are included in the chapter's Creative Commons licence, unless indicated otherwise in a credit line to the material. If material is not included in the chapter's Creative Commons licence and your intended use is not permitted by statutory regulation or exceeds the permitted use, you will need to obtain permission directly from the copyright holder.

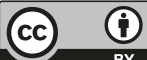

